\title{
A LOOK AT 'THE ORCHID BOOK' IN CELEBRATION OF CHARLES DARWIN'S 200TH BIRTHDAY
}

\author{
Kenneth M. CAmeron \\ Wisconsin State Herbarium and Department of Botany, University of Wisconsin \\ Madison, Wisconsin 53706 U.S.A. \\ kmcameron@wisc.edu
}

\begin{abstract}
On February 12, 2009, the world celebrated the 200th birthday of Charles Darwin. His contributions to the study of evolution and human origins are well known, but his botanical research is underappreciated. Darwin published nine different books that focused on domesticated plants, insectivorous plants, climbing plants, and other botanical subjects, but his study on orchids is the most notable because it was the first book he published after the Origin of Species (1859). Darwin's book On the Various Contrivances by which British and Foreign Orchids are Fertilised by Insects (1862) was a systematic overview of both temperate and tropical orchid groups and their pollinators. The nine chapters treated members of Orchideae, Arethuseae, Neottieae, Vanilleae, Malaxideae, Epidendreae, Vandeae, Cymbidieae (especially Catasetum), and Cypripedioideae. Orchid flowers were described and illustrated by Darwin in great detail, careful observations on pollinator behavior were recorded, and a healthy dose of speculation was presented. Our understanding of the phylogeny, pollination, physiology, and overall natural history of these orchid groups has advanced tremendously in the last 150 years. Few people realize that "the orchid book" is subtitled, “. . . and on the Good Effects of Intercrossing." That subject was of great concern to Darwin, and the orchids provided concrete examples necessary to substantiate his theory. Even today, orchids and Darwin's orchid book continue to inspire evolutionary biologists and exemplify the power of natural selection.
\end{abstract}

Resumen. En febrero 12 de 2009, el mundo celebró el 200avo cumpleaños de Charles Darwin. Sus contribuciones al estudio de la evolución y los orígenes del hombre son bien conocidos, pero su investigación botánica no ha sido apreciada en su justa medida. Darwin publicó nueve libros diferentes que se enfocaron sobre plantas domesticadas, plantas insectívoras plantas trepadoras, y otros temas botánicos, pero el más notable es su estudio sobre las orquídeas, ya que fue el primer libro publicado después del Origen de las Especies (1859). El libro de Darwin, Sobre las estrategias por las cuales las orquídeas británicas y las introducidas son fertilizadas por insectos (Darwin, 1862), fue una visión a la sistemática de las orquídeas de zonas templadas y tropicales y de sus polinizadores. Los nueve capítulos tratan especies de Orchideae, Arethuseae, Neottieae, Vanilleae, Malaxideae, Epidendreae, Vandeae, Cymbidieae (especialmente Catasetum) y Cypripedioideae. Las flores de las orquídeas fueron descritas y estudiadas por Darwin con gran detalle, cuidadosos registros del comportamiento de los polinizadores fueron mantenidos, y una gran dosis de especulación fue agregada. Nuestra comprensión de la filogenia, polinización, fisiología, y toda la historia natural de estos grupos han avanzado tremendamente en los últimos 150 años. Pocas personas han notado que "el libro de las orquídeas", se subtitula... "y sobre el Buen Efecto del Entrecruzamiento". Fenómeno que fue de gran interés para Darwin y las orquídeas brindaron ejemplos concretos para substanciar su teoría. Aún en nuestros tiempos, el libro de "Orquídeas" de Darwin, continúa inspirando a los biólogos evolucionistas y ejemplifica el poder de la selección natural.

KeY wORDS: Charles Darwin, Orchidaceae, pollination

It was fitting that the Third International Conference on Andean Orchids was held in Ecuador in 2009. This country of only 256,371 square kilometers $(98,985$ square miles) boasts some of the most diverse ecosystems on Earth - from the Amazon rain forest in the east across the Andes mountains and ultimately to the Galapagos Islands $972 \mathrm{~km}$ (604 miles) west of the Ecuadorian mainland. Indeed, because of their high 
levels of biological diversity, the Andes have been called a cradle of evolution and the Galapagos the cradle of evolutionary theory. Why? Because from 1831-1836, the young English naturalist Charles Darwin sailed aboard the well-known expeditionary vessel, HMS Beagle, collecting flora and fauna along both the eastern and western coastlines of South America. It was during his time among the islands of the Galapagos, however, that Darwin made some of his most inspiring observations. These would ultimately serve to catalyze his theory of evolution by natural selection, which would eventually be detailed and published in 1859 - exactly 150 years ago. While the world celebrates the anniversary of On the Origin of Species (Darwin, 1859) this year, it also celebrates what would have been Darwin's 200th birthday (he was born February 12, 1809). For these reasons, Darwin's contributions to botany, and orchid biology in particular, are worthy of consideration this year, and it was all the more fitting to do so in Ecuador.

\section{The young naturalist/botanist}

Darwin's detailed descriptions of tortoises, finches, iguanas, and other vertebrate animals are well known, but the public is generally ignorant of Darwin's considerable contributions to plant biology. His interest in the "Vegetable Kingdom" must have developed at an early age and was only cultivated further by regular interactions with his teachers, friends, and colleagues who shared a similar passion for the natural sciences. Among the most influential scientists in Darwin's life were botanists, including John S. Henslow. Professor Henslow joined the faculty of Geology at Cambridge University in 1822 but five years later resigned from his position as Professor of Mineralogy after becoming Professor of Botany, a subject he held in higher regard and interest. Darwin owed much to Henslow for steering him into the study of natural history and also for introducing him to such wellrespected botanists as Joseph Dalton Hooker, who would become his closest friend. Hooker married Professor Henslow's daughter and would eventually serve as Director of the Royal Botanic Gardens, Kew, for 20 years. At Kew, Charles Darwin eventually would be introduced by Hooker to the greatest American botanist of the 19th century,
Asa Gray, and the two men would develop a close professional relationship through regular written correspondence. There is no doubt that the shared passion for botany among all of these men cemented their friendships but would also certainly have had a direct influence on their independent intellectual pursuits.

Among the first pieces of evidence that we have to show how the study of plants may have influenced Darwin's construction of a case for evolution by natural selection is to be found in his Journal and Remarks of the Voyage of the Beagle (Darwin, 1839). Within the pages of this best-selling book it is well known that he documented the fact that different bird species inhabited different islands in the archipelago, each apparently adapted to its unique environment, but Darwin also documented the same phenomenon with some of the endemic plant species that he encountered:

If we now turn to the Flora, we shall find the aboriginal plants of the different islands wonderfully different... Scalesia, a remarkable arborescent genus of the Compositæ, is confined to the archipelago: it has six species; one from Chatham, one from Albemarle, one from Charles Island, two from James Island, and the sixth from one of the three latter islands: not one of these six species grows on any two islands. The species of the Compositæ are particularly local; in like manner we have seen that the different islands have their proper species of the mundane genus of tortoise, and of the widely distributed American genus of the mocking-thrush, as well as of two of the Galapageian sub-groups of finches.

It would not be for another 20 years that Darwin would make his greatest contribution to science by publishing On The Origin of Species (Darwin, 1859). Much has been written about this pivotal work, Darwin's most important, and the reader is encouraged to explore the book or at least to take a moment in order to reflect on its importance to human society. After being thrust into the spotlight of fame and controversy, however, Darwin did not end his basic research. In fact, he continued to publish until his death in 1882. It is generally underappreciated that during those intervening 23 years, most of Darwin's texts were focused on various aspects 
of plant biology. They included books on insectivorous plants, climbing plants, plant movements, flowers, and orchids (see Table 1). In fact, the next book to be published immediately after the Origin was his 300page treatise, On the Various Contrivances by which

TABlE 1. Charles Darwin's published books. Those with fairly strong or exclusively botanical themes are in boldface: 9 of $21=43 \%$.

\section{9: Journal and Remarks (The Voyage of the} Beagle)

1842: The Structure and Distribution of Coral Reefs

1844: Geological Observations of Volcanic Islands

1846: Geological Observations on South America

1849: Geology from A Manual of Scientific Enquiry; Prepared for the Use of Her Majesty's Navy: and Adapted for Travellers in General., John F. W. Herschel, ed.

1851: A Monograph of the Sub-class Cirripedia, with Figures of All the Species. The Lepadidae; or, Pedunculated Cirripedes.

1851: A Monograph on the Fossil Lepadidae; or, Pedunculated Cirripedes of Great Britain

1854: A Monograph of the Sub-class Cirripedia, with Figures of All the Species. The Balanidae (or Sessile Cirripedes); the Verrucidae, etc.

1854: A Monograph on the Fossil Balanidce and Verrucidce of Great Britain

1858: On the Tendency of Species to form Varieties; and on the Perpetuation of Varieties and Species by Natural Means of Selection (Extract from an Unpublished Work on Species)

1859: On the Origin of Species by Means of Natural Selection

1862: On the Various Contrivances by which British and Foreign Orchids are Fertilised by Insects

1868: Variation of Plants and Animals Under Domestication

1871: The Descent of Man, and Selection in Relation to Sex

1872: The Expression of Emotions in Man and Animals

1875: Movement and Habits of Climbing Plants

1875: Insectivorous Plants

1876: The Effects of Cross and Self Fertilisation in the Vegetable Kingdom

1877: The Different Forms of Flowers on Plants of the Same Species

1880: The Power of Movement in Plants

1881: The Formation of Vegetable Mould Through the Action of Worms
British and Foreign Orchids are Fertilised by Insects (Darwin, 1862). The book contained 35 illustrations. While orchidologists today continue to find inspiration among the pages of this text, specialists in other disciplines such as the history of science have devoted considerable attention to the subtitle of the book, "..., and on the Good Effects of Intercrossing".

\section{Inbreeding and outcrossing}

Darwin emphasized the roles of inbreeding and outcrossing in formulating his theory of evolution and would later write an entire book on the subject - Effects of Cross and Self Fertilisation in the Vegetable Kingdom (Darwin, 1876). After all, variation is the raw material of evolution by natural selection, and even though Darwin was not familiar with Mendelian genetics, he and others, especially livestock breeders, knew that sexual reproduction among unrelated individuals had the potential to produce a higher level of variation than did inbred lines. But Darwin's interest in the subject may have been more than academic. It has been argued (Moore, 2005) that he had a personal interest in the subject of inbreeding, for the Darwin and Wedgwood families had intermarried for several generations. Of the 62 aunts, uncles, and cousins born in the four generations founded by Charles Darwin's grandparents, Josiah and Sarah Wedgwood, 38 (61\%) remained childless. Specifically, a total of 19 (73\%) of the 26 children born from the first-cousin marriages in the "Darwood" family did not reproduce. Perhaps some of these couples chose to remain childless. Others may have lost children due to lack of modern medical care (although the families were both wealthy and would have had access to the best physicians of the day). It is likely, however, that this high level of infertility (i.e., reduced "fitness" in the sense of evolutionary theory) was due to genetic defects caused by inbreeding among the close relatives. Charles Darwin almost certainly recognized this fact. Even he married his first cousin, Emma Wedgwood, and several of their children died young (3 of 10) or suffered serious health problems. Only 3 of their 7 living children produced grandchildren for Charles and Emma. Could Darwin's personal family life have influenced the development of his theory of evolution with its emphasis on fitness defined by reproductive potential and descent from parent to offspring? Some believe that this was precisely the case (Moore, 2005). 
Whatever the reason, Darwin went forth by publishing his orchid book to demonstrate that natural selection not only serves to explain animal evolution but plant evolution as well. One might assume that plants tend to self-pollinate (inbreed) more than do animals, because the former are stationary and their flowers generally hermaphroditic. If this were true, it would be a serious flaw in Darwin's theory. Thus, he argued that outcrossing among plants must be more common than perceived, and he used as examples the complex behavior of orchid pollinators coupled with detailed descriptions of orchid floral structure to demonstrate that these, and most likely other plants as well, are perfectly adapted to avoid selfing. In fact, when you think about it, what better group of organisms to document this fact than orchids, which have hermaphroditic flowers in which male and female organs are intimately united into one. This is certainly an extreme case that would appear at first glance to promote selfing if ever there was one! This fact was not lost on Darwin, who stated in the book that "unless we bear in mind the good effects which have been proved to follow in most cases from cross-fertilisation, it is an astonishing fact that the flowers of Orchids should not have been regularly self-fertilised. It apparently demonstrates that there must be something injurious in this latter process, of which I have elsewhere given direct proof." He concluded the orchid book stating that "it is hardly an exaggeration to say that Nature tells us, in the most emphatic manner, that she abhors perpetual self-fertilisation."

While the advantage of outcrossing is a theme that runs through the entire orchid book, the fact that Darwin published it immediately after the Origin of Species leads us to believe that he had other motives as well. In his rush to publish the Origin as quickly as possible (as what he called an unfinished "abstract"), Darwin was unable to provide all of the supporting material that he felt bolstered his argument. Critics were quick to attack, and the orchid book served as a partial response. Darwin wrote to his publisher, John Murray, on September 24, 1861, "I think this little volume will do good to the 'Origin', as it will show that I have worked hard at details." These detailed examples were provided not only for other naturalists but also for so-called natural theologians who were beginning to accept many of the facts presented by geologists, paleontologists, and biologists in terms of the origins and antiquity of life but still saw God as the force guiding all laws of nature. Just as people today continue to debate the driving force of evolution either by means of natural selection or the hand of a creator, so they did as well in the mid-19th century as the Origin became a bestseller. Throughout the book Darwin dismisses what today might be called intelligent design in orchid flowers and instead provides example after example of what he regularly called "perfect adaptation." For example, Darwin felt no need to invoke the hand of God in referring to the flowers of Spiranthes autumnalis as a "perfect adaptation by which the pollen of a younger flower is carried to the stigma of an older flower." Asa Gray would later state that "if the Orchid-book (with a few trifling omissions) had appeared before the 'Origin' the author would have been canonised rather than anathematised by natural theologians."

Among the most celebrated of the detailed examples provided by Darwin in the orchid book is his hypothesis concerning the pollination of Angraecum sesquipedale. This orchid species endemic to Madagascar is often referred to as the "comet orchid" because of its unusually long nectar spur (the specific epithet of the species, sesquipedale, translates to 'a foot and a half'). Although the sphyngid moth pollinator of the comet orchid (Xanthopan morganii praedicta) would not be discovered until 1903, and in situ observations of visitation events would not be recorded on video until the early 21 st century, Darwin's hypothesis for explaining the co-evolution between the orchid and insect would prove to be a classic example of the predictive power of evolutionary biology. In his own words, Darwin explained that "We can thus understand how the astonishing length of the nectary had been acquired by successive modifications . . . As certain moths of Madagascar became larger through natural selection in relation to their general conditions of life [or their proboscis became elongated] . . . those individual plants of the Angraecum which had the longest nectaries (and the nectary varies much in length in some Orchids) ... would be best fertilised. These plants yield the most seed, and the seedlings would generally inherit long nectaries; and so it would be in successive generations of the plant and the moth." 


\section{The orchid book, chapter by chapter}

To this day, Darwin's orchid book remains a mustread for any botanist, and especially for those of us interested in orchidology. Yam et al. (2009) examined the influence of the book on aspects of orchid biology other than pollination ecology, such as physiology, structure, and taxonomy. They also provided a more detailed account of how the book came to be, and the reader who desires further information is encouraged to consult their paper. As a summary, however, I will present an overview of the book, chapter by chapter.

The first edition (Darwin, 1862) treated 63 genera of orchids, and included 34 illustrations dispersed among 365 pages of text. These were divided into seven chapters. By the time that edition sold out and a second edition was printed (Darwin, 1877; Fig. 1), Darwin had access to a great many more orchid taxa, especially from the Neotropics, Australia, and temperate North America. These included Pterostylis, Caladenia, Thelymitra, Disa, Gongora, Sobralia, Pogonia, Platanthera, and others. In total, the second edition was expanded to treat 85 different genera of orchids (a 35\% increase), four additional illustrations were provided, and the chapters were reorganized into nine. For the most part, these were arranged according to the accepted classification system of the day as proposed by John Lindley (1827). Subfamilies were not considered, but Orchidaceae (excluding apostasioid orchids) were divided into tribes.

Chapters 1 and 2 treat Ophreae, in particular the European terrestrial orchids such as Orchis and Ophrys, the bee orchids. A total of 73 pages were devoted to detailed observations and experimentation with the orchids with which Darwin would have been most familiar because they grew near his home in the English countryside. Among the genera considered are Orchis, Ophrys, Herminium, Peristylus, Gymnadenia, Platanthera, Habenaria, Disa, and Bonatea.

Chapter 3 and 4 are short and consider tribes Arethuseae and Neottieae, respectively. Although Vanilla is recognized today as only distantly related to these lower epidendroid groups, it was treated among the 12 pages of Chapter 3. Among the other genera discussed here are Cephalanthera, Sobralia, Pterostylis, Caladenia, and Pogonia. More recent systems of classification, especially those based on DNA evidence

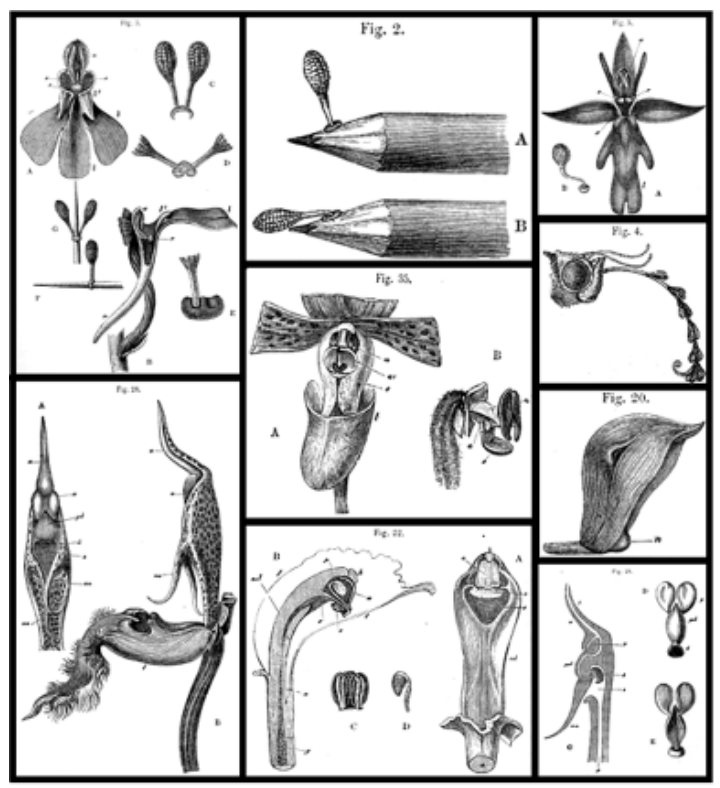

FIgURE 1. A selection of nine original figures from Charles Darwin's (1877) The Various Contrivances by which Orchids are Fertilised by Insects. 2nd edition.John Murray, London.

(e.g., Chase et al., 2003) have demonstrated that these orchids, which share plesiomorphic aspects of their floral morphology, actually belong to three different subfamilies. Likewise, many of the genera considered together in Lindley's concept of tribe Neottieae and discussed by Darwin in Chapter 4 (Epipactis, Listera, Neottia, Epipogium, Goodyera, Spiranthes, Thelymitra) are now classified among different tribes of subfamilies Orchidoideae and Epidendroideae. Darwin devoted 34 pages to them.

The subsequent chapters of the orchid book treated those orchids classified within Epidendroideae, the largest subfamily of Orchidaceae. Today we count nearly 20,000 different species in that group. However, in Darwin's day less than 2000 orchid species were recognized in total. It is almost humorous to note that Lindley estimated that there might be as many of 6000 orchid species to be discovered eventually. It might not be surprising, therefore, to realize that Darwin only devoted 20 pages of text in Chapter 5 to tribes Malaxeae and Epidendreae. These are primarily tropical orchid tribes, and many of the most species-rich genera were still poorly collected, especially those from higher elevations of the Andes, New Guinea, and southeast 
Asia. Among the genera that were known to Darwin - primarily through relationships with horticulturists at Kew and from other glasshouse collections - were Malaxis, Bulbophyllum, Dendrobium, Cattleya, Laelia, Epidendrum, Pleurothallis, and Stelis. Darwin was intrigued by the odd flowers of Zootrophion atropurpureum, which he knew and illustrated in Figure 20 as Masdevallia fenestrata. The taxonomy of the orchids treated by Darwin has changed considerably over the past century and is presented below as an Appendix. The names as they appeared in the second edition of the orchid book as well as their currently accepted names are provided for comparison.

Following in sequence we reach Chapters 6 and 7 , which are 74 pages in length and devoted to the plants Darwin said were "the most remarkable of all orchids." These are members of tribe Vandeae (as then understood), and particular emphasis was given to Catasetum and its fast-action mechanism of pollinarium ejection. This is not surprising because Darwin was obviously fascinated by plant movement. In 1875, he published Movement and Habits of Climbing Plants. That same year, his Insectivorous Plants considered the movement of sundews (Drosera spp.) and Venus' flytrap (Dionaea muscipula Ellis). In 1880, he published The Power of Movement in Plants. Other orchids discussed in chapters 6 and 7 of the orchid book are Calanthe, Miltonia, Sarcanthus, Maxillaria, Angraecum, Coryanthes, Mormodes, and Cycnoches.

Chapter 8 is devoted to the lady's-slipper orchids, with one genus (Cypripedium) at that time classified into tribe Cypripedieae. Among the 20 pages is also found a discussion concerning the homologies of orchid floral organs. This is a wonderful chapter in which Darwin demonstrated his skill as a keen observer and experimental biologist. For example, he described several attempts to introduce various insects to the flowers of Cypripedium calceolus in order to record their behavior, only to find that some "were either too large or too stupid, and did not crawl out properly." Originally he felt sure that lady's slipper orchids were pollinated when "insects alighted on the labellum and inserted their proboscides through either of the orifices close to the anthers," but later realized that this made little sense given that "if an insect were to insert its proboscis, as I had supposed, from the outside through one of the orifices, ... the stigma would be liable to be fertilized by the plant's own pollen." This would be contrary to the argument made throughout the book in favor of mechanisms to ensure cross-fertilization, and so he was delighted to document that his experiments proved just the opposite -Cypripedium also manages to avoid self-pollination.

An example of a hypothesis presented in the book that would eventually be proven incorrect, however, can be found in this chapter. Figure 36 in the book shows an artificial section through a monandrous orchid flower. At the time it was assumed that three anthers of an ancestral inner androecial whorl were modified to form the orchid clinandrium and apex of the column. One of the anthers from the outer whorl remained fertile, leaving two others "of the same whorl combined with the lower petal, forming the labellum." Today the structure and homologies of the orchid labellum are not viewed in this way. There is no evidence that sterile stamens or anthers are involved in its construction.

Finally, in Chapter 9, titled 'Gradation of Organs, etc. \& Concluding Remarks', Darwin provides a summary of the various examples he has presented throughout the book, and makes his final arguments. He states, "it may naturally be inquired, Why do the Orchideae exhibit so many perfect contrivances for their fertilization? From the observations of various botanists and my own, I am sure that many other plants offer analogous adaptation of high perfection; but it seems that they are really more numerous and perfect with the Orchideae than with most other plants." From that statement alone it is clear that Charles Darwin had a passion for orchids. One might even say that he contracted what today some would call orchid fever! During in his life he would write to colleagues such statements as "you cannot conceive how the orchids have delighted me" (Darwin, 1861a), "I am sillily and very idly interested in them" (1860), "the orchids are more play than real work", and "the orchids have been a splendid sport" (Darwin, 1862b). This highly respected and influential scientist, a man who was passionate about animal and plant biology and who would do so much to advance evolutionary theory, would state that "orchids have interested me more than almost anything in my life" (Darwin, 1861b). Many of us today feel the same and should feel pride, but also humility, in following his footsteps. 


\section{APPENDIX}

Genera and species of Orchidaceae referenced in Darwin (1877). Page numbers are provided based on this edition, and spellings are reproduced exactly as they appear within the index of the book. Names within brackets are those accepted currently by the World Checklist of Monocotyledons. (2009). The Board of Trustees of the Royal Botanic Gardens, Kew. Published on the Internet; http://www.kew.org/wcsp/monocots/ accessed 2 August 2009.

Aceras anthropophora, 26, 258 [Orchis anthropophora]

- longibracteata, 26 [Barlia robertiana]

Acianthus exsertus, 90

- fornicatus, 90, 280

- sinclairii, 90, 280

Acontia luctuosa, 31 [Acronia luctuosa = Pleurothallis luctuosa]

Acropera, 154, 156, 276 [Gongora]

— loddigesii, 166 [Gongora galeata]

— luteola, 166, 239 [Gongora galeata]

Aerides, 156, 265

— cornutum, 265 [Aerides odorata]

- odorata, 158

— virens, 156 [Aerides odorata]

Angracum, 251

— distichum, 154

- eburneum, 155

- sesquipedale, 154, 162, 282, 265

Apostasia, 248

Barkeria, 146

Bolbophyllum, 274, 276 [Bulbophyllum]

— barbigerum, 138

- cocoinum, 137

- cupreum, 137, 265

— rhizophorce, 137 [Bulbophyllum falcatum var. velutinum ]

Bonatea speciosa, 71, 76, 244, 264, 361

Brassia, 156

Caladenia dimorpha, 89

Calcena, 89 [Caleana]

Calanthe dominii, 161 [Calanthe $\mathrm{x}$ dominii]

- masuca, 161, 267, 269 [Calanthe sylvatica]

— veratrifolia, 280 [Calanthe triplicata]

- vestita, 162

Catasetum, 256, 270

- callosum, 192, 195

- luridum, 191

- mentosum, 206

- planiceps, 193

- saccatum, 180-185, 239

- tabulare, 192
— tridentatum, 191, 196, 197,239,256,269 [Catasetum macrocarpum]

Cattleya, 143-148 , 239, 265

— crispa, 147 [Sophronitis crispa]

Cephalanthera, 277

— ensifolia, 86 [Cephalanthera longifolia]

- grandiflora, 80-86, 239, 242, 249, 259, 269, 277, 287, 290 [Cephalanthera longifolia]

Chysis, 146

Cirrhcea, 171

Coelogyne cristata, 146

Coryanthes, 90, 173, 232, 265

- fieldingii, 175

- macrantha, 175

- speciosa, 174

— triloba, 281 [?]

Cycnoches egertonianum, 224

- ventricosum, 220-224

Cymbidium giganteum, 155, 252, 260, 263 [Cymbidium iridiodes]

Cypripedium, 226, 229, 262, 275

- acaule, 229

- barbatum, 239 [Paphiopedilum barbatum]

- calceolus, 229-231, 282

- candidum, 235

— pubescens, 229, 230 [Cypripedium parviflorum var. pubescens]

— purpuratum, 239 [Paphiopedilum purpuratum]

Cyrtostylis, 90

Dendrobium, 287

- bigibbum, 142

- chrysanthum, 138-142, 265

— cretaceum, 142, 291 [Dendrobium polyanthum]

- formosum, 142

- speciosum, 281

- tortile, 142

Disa, 265

— cornuta, 78

- grandiflora, 77, 281 [Disa uniflora]

- macrantha, 78, 290 [Disa cornuta]

Disperis, 265 
Epidendrum cochleatum, 249 [Prosthechea cochleata]

— floribundum, 146, 249 [Epidendrum paniculatum]

— glaucum, 146 [Dichaea glauca]

Epipactis, 239, 251

—latifolia, 100, 101, 259, 282, 287 [Epipactis helleborine]

- microphylla, 102

— palustris, 93-100, 275

- purpurata, 102

— rubiginosa, 102 [Epipactis atrorubens]

— viridiflora, 102, 291 [Epipactis purpurata]

Epipogium gmelini, 103 [Epipogium aphyllum]

Eulophia viridis, 156, 269 [? Eulophia viridiflora $=$ Eulophia epidendraea]

Evelyna, 265 [Elleanthus]

- carivata, 146, 239, 241 [Elleanthus caravata]

Galeandra funkii, 155 [Galeandra baueri]

Glossodia, 237

Gongora, 276

— atropurpurea, 169

— maculata, 168

- truncata, 169

Goodyera, 239, 260

— discolor, 105 [Ludisia discolor]

Goodyera pubescens, 105

- repens, 103, 105

Gymnadenia, 251

— albida, 43, 68 [Pseudorchis albida]

- conopsea, 32 , 40, 43, 65, 238, 239, 255, 271, 272

- odoratissima, 68

— tridentata, 68, 291 [Platanthera clavellata]

Habenaria bifolia, 78, 40, 43, 251 [Platanthera bifolia]

Habenaria chlorantha, 43, 69, 239, 244, 251

[Habenaria viridiflora]

Herminium monorchis, 59, 61, 255

Lcelia, 146

— cinnabarina, 148 [Sophronitis cinnabarina]

Leptotes, 146

Liparis pendula, 239, 241 [Stichorkis viridiflora]

Listera, 251, 287 [Neottia]

— cordata, 124 [Neottia cordata]

— ovata, 115-124, 276 [Neottia ovata]

Lycaste skinneri 155, 260

Malaxis, 251, 276

- paludosa, 32, 129-135, 239, 241, 241, 258, 284 [Hammarbya paludosa]

Masdevallia, 241, 274, 276
— fenestrata, 135, 136, 142 [Zootrophion fenestratus] Maxillaria, 156, 278

—ornithorhyncha, 157, 159 [?]

Megaclinium falcatum, 138 [Bulbophyllum falcatum]

Microstylus rhedii, 132, 135 [Malaxis resupinata]

Miltonia clowesii, 154, 155

Monachanthus viridis, 196, 197, 198, 201 [Catasetum cernuum]

Mormodes ignea, 208-219, 249, 276, 283

- luxata, 219

Myanthus barbatus, 192, 199, 203, 205 [Catasetum barbatum]

Neotinia intacta, 27, 291 [Neotinea maculata]

Neottia nidus-avis, 125, 258, 290

Nigritella angustifolia, 27 [Gymnadenia nigra]

Notylia, 171

Odontoglossum, 156

Oncidium, 153, 156, 158, 239, 251, 266

- unguiculatum, 252

Ophrys apifera, 52, 54-58, 259, 279, 291

— arachnites, 51 [Ophrys apifera]

— aranifera, 50, 280 [Ophrys sphegodes]

— muscifera, 32, 45, 49, 280 [Ophrys insectifera]

- scolopax, 52, 292

Orchis fusca, 15, 35, 37 [Orchis purpurea]

— hircina, 25, 39, 273 [Himantoglossum hircinum]

— latifolia 15, 35, 37, 255 [Dactylorhiza incarnata]

- maculata, 15, 34, 32 , 35, 37, 39, 255, 255, 277, 278

[Dactylorhiza maculata]

Orchis mascula, 6, 273, 278

— militaris, 36, 37

-morio, 15, 128, 33, 37, 39, 278 [Anacamptis morio]

— pyramidalis, 16, 21, 34, 37, 39, 38, 254, 256, 260, 261, 264, 272, 273 [Anacamptis pyramidalis]

- ustulata, 25 [Neotinea ustulata]

Ornithocephalus, 160

Peristylus viridis, 43, 63, 255 [Coeloglossum viride]

Phaius, 146

— grandifolius, 280 [Phaius tankervilleae]

Phalaenopsis, 153, 159, 276

— amabilis, 159

— grandiflora, 159, 269 [Phalaenopsis amabilis]

Platanthera, 75

- chlorantha, 69

— dilatata, 77 [Piperia dilatata]

- flava, 76, 77

- hookeri, 75 
- hyperborea, 76, 291

Pleurothallis ligulata, 135 [Stelis ligulata]

— prolifera, 135 [Acianthera prolifera]

Pogonia ophioglossoides, 86

Pterostylis, 232

— longiflora, 87, 89 [? Pterostylis longifolia]

— trullifolia, 86, 88, 280

Rodriguezia secunda, 159 [Rodrigueza lanceolata]

— suaveolens, 156, 159 [Gomesa foliosa]

Saccolabium, 153, 156

Sarcanthus, 276 [Cleisostoma]

— parishii, 142 [Cleisostoma parishii]

— teretifolius, 154, 156, 268 [Cleisostoma simondsii]

Selenipedium palmifolium, 232

Serapias cordigera, 27

Sobralia macrantha, 91

Sophronitis, 146
Spiranthes australis, 114, 275, 291 [Spiranthes sinensis]

— autumnalis, 106-114, 239

- cernua, 111

— gracilis, 111 [Chlorosa gracilis]

Stanhopea, 155, 276

— devoniensis, 171 [Stanhopea hernandezii]

- oculata, 171

Stelis, 274

— racemiflora, 135 [Stelis quadrifida]

Thelymitra, 291

- carnea, 127, 280

— longiflora, 127 [? Thelymitra longifolia]

Uropedium, 240 [Phragmipedium]

Vanilla aromatica, 90 [Vanilla planifolia]

Warrea, 155, 270

Zygopetalum mackai, 155 [Zygopetalum maculatum]

\section{LITERATURE CITED}

Chase, M. W., K. M. Cameron, R. L. Barrett \& J. F. Freudenstein. 2003. DNA data and Orchidaceae systematics: a new phylogenetic classification. Pp. 69-89 in: K. W. Dixon, S. P. Kell, R. L. Barrett, and P. J. Cribb (eds.). Orchid conservation. Natural History Publications, Kota Kinabalu, Sabah, Malaysia.

Darwin, C. R. 1859. On the origin of species by means of natural selection, or the preservation of favoured races in the struggle for life. John Murray, London, UK.

Darwin, C. R. 1860. Letter 2892 - Darwin, C. R., to Hooker, J. D., 7 Aug. 1860. Vol. 8, p. 313 in: F. Burkhardt, J. Browne, D. M. Porter, and M. Richmond (eds.). The correspondence of Charles Darwin (ed. 1993). Cambridge University Press, UK.

Darwin, C. R. 1861a. Letter 3220 - Darwin, C. R., to Hooker, J. D., 27 July 1861. Vol. 9, p. 220 in: F. Burkhardt, J. Browne, D. M. Porter, and M. Richmond (eds.). The correspondence of Charles Darwin (1994). Cambridge University Press, UK.

Darwin, C. R. 1861b. Letter 3289 - Darwin, C. R., to Lindley, John, 18 Oct. 1861. Vol. 9, p. 308 in: F. Burkhardt, J. Browne, D. M. Porter, and M. Richmond (eds.). The correspondence of Charles Darwin (1994). Cambridge University Press, UK.

Darwin, C. R. 1862a. Letter 3484 - Darwin, C. R., to Hooker, J. D., 26 Mar. 1862. Vol. 10, p. 135 in: F. Burkhardt, J. Browne, D. M. Porter, and M. Richmond (eds.). The correspondence of Charles Darwin (1997). Cambridge University Press, UK.

Darwin, C. R. 1862b. On the various contrivances by which British and foreign orchids are fertilised by insects and the good effects of intercrossing. John Murray, London, UK.

Darwin, C. R. 1877. On the various contrivances by which British and foreign orchids are fertilised by insects, 2 nd ed. John Murray, London, UK.

Lindley, J. 1830-1840. The genera and species of orchidaceous plants. Ridgways, London, UK.

Moore, J. 2005. Good breeding. Nat. Hist. 114: 45-46.

World Checklist of Monocotyledons. (2009). The Board of Trustees of the Royal Botanic Gardens, Kew. Published on the Internet; http://www.kew.org/wcsp/monocots/ accessed 2 August 2009.

Yam, T. W., J. Arditti \& K. M. Cameron. 2009. The orchids have been a splendid sport: an alternative look at Charles Darwin's contribution to orchid biology. Amer. J. Bot. 96: 1-27. 